\title{
Leadership Hiring: Does the Promotional Practice and Selection in Public Service Result in Placing Highly Skilled Experts in Our Communities?
}

http://doi.org/10.21272/bel.5(1).98-108.2021

Damon Brown, ORCID: https://orcid.org/0000-0002-7145-7898

Ed.D. MA, Training Coordinator, Department of State, Washington D.C., USA

\begin{abstract}
Primarily, this technical article intends to address the hiring practices of executive police leadership. The article questions police executives' capability based upon a significant number of police chiefs exiting their position for several reasons related to the summer of 2020, whereas several societal crises ensued. The article demonstrates how police executives are not hired based on their ability to be capable leaders or, highly skilled experts but are repeatedly hired based upon tenure, deemed as qualified. Subjective measures exclude specific demographics, human and conceptional skills, and the lack of community input from the societies they are appointed to serve are continually used to hire police leaders. Additionally, the subsequent promotional exams allowing aspiring police leaders are subjective, demonstrated by the multiple suits filed from across the country, as is the proper selection or lack of essential training such as entry to the FBI academy law enforcement training. A specific model, the Three Skill Approach, outlines the various skills for selection criteria. The article asserts that other models can be employed, emphasizing that multiple skills within potential leaders are critical. Also strongly suggested in the report is that the community in which police serve must be aware of how police executives are selected and included in that process, allowing for a partnership between the police leadership and the community. Often, unknown to the community is the right to articulate and establish how they are policed, which can only be realized by a leader who has the multiple skills and has developed a genuine relationship with the community, eventually seen as part of the community.
\end{abstract}

Keywords: Leadership, Hiring, Police, Community, Promotion, Appointment, Selection.

JEL Classification: C52, M51.

Cite as: Brown, D. (2021). Leadership Hiring: Does the Promotional Practice and Selection in Public Service Result in Placing Highly Skilled Experts in Our Communities? Business Ethics and Leadership, 5(1), 98-108. http://doi.org/10.21272/bel.5(1).98-108.2021.

Received: 15 January 2021

Accepted: 10 March 2021

Published: 30 March 2021

Copyright: (C) 2021 by the author. Licensee Sumy State University, Ukraine. This article is an open access article distributed under the terms and conditions of the Creative Commons Attribution (CC BY) license (https://creativecommons.org/licenses/by/4.0/).

\section{Introduction}

Issues in police leadership have been written about and discussed for over 175 years, dating back to Sir Robert Peel. Peel assisted in establishing the London Metropolitan Police Act of 1829 in England (Decker, 2018). It is then no surprise that we are currently continuing to enhance police leadership. Leadership is integral to overall police reform; therefore, it is important to select, seat, and appoint an executive-level police leader who not only has tenure but has the other skills to be successful in today's increasingly complex society. The ultimate focus for leadership is to bring about improved performance (Dobby et al., 2014). One would believe that the police problem is not a social problem or does not include other professions and communities, even though research does not support that assumption. Prior research has focused on the antecedents of increased levels of leadership performance, including human resource practices (Graham, Zheng, Epitropaki \& Snape, 2019). The procedures used to obtain leaders through human resource or government official appointment are void of some essential aspects, albeit leadership skills leading to a highly skilled expert and community involvement or community policing. Effective leadership selection relies upon the progressive ability of the human resource team to obtain factual and intangible details related to the leadership candidate (Rozario, Venkatraman \& Abbas, 2019). While many skills and traits can lead to effective and capable leadership, most human resource announcements and selection criteria omit those critical traits and abilities. In the past, human resources have focused heavily on professional tenure. The definition of professional tenure is the time an employee has spent 
in their organization or profession (Kim, 2018). Tenure assumes that the candidate has gained knowledge of the domain to the extent that he/she can lead a department or agency successfully. Tenure does not allow for an assessment of leadership skills, the skills needed to lead in the world of 21 st century policing. Mainly relying on tenure alone or even heavily does not mean that the desired learning or skill achievement has occurred. As the police culture implies that it has been handed down decade after decade historically established from an inequitable context, proper leadership selection is paramount to engage in cultural change. Dobby et al. (2004) mentioned those police organizations were troubled by corruption, violence, and discrimination and went on to suggest, these issues permeated through the ranks of the "Political Era" police departments, and often the chief or commissioner is embedded in these behaviors and ideologies (Decker, 2018). The overall promotional process of public safety officers typically uses "job knowledge" examinations. All fit a familiar pattern - near-total exclusion of minority applicants, and no evidence showing that the devices could meaningfully predict successful job performance as a supervisor (Brodin, 2018). The above-described promotional process not only results in a less than adequate vetting process for supervisors but precludes minorities who are not only a part of American society but are representatives of their respective communities and dedicated to public service.

\section{Literature Review}

Leadership in public service, particularly police leadership, is integral to the well-being and perceived safety of the communities they serve. Most studies and articles concerning police leadership are focused on how influential the leaders are. The general conclusion reached is that administrators have considerable managerial prerogatives under State and Federal law to implement hiring standards and procedures to ensure police executives are competent and have developed the expertise to lead a police department (Schoefield, 1993). Subsequently, administrations are capable of seating an executive police leader who is a highly skilled expert. However, it is this specific focus of literature concerning police leadership that may be inadequate. International research on police leadership has primarily revolved around characterization (i.e., transactional or transformative), what the effects of leadership are or, how the specific conditions and culture(s) of the police inform leadership practices (Haake, Rantatalo \& Lindberg, 2015). A unique and early study on selecting leadership in policing was the Wickersham Commission's Report on Police article by Vollmer (1931). Volmer contended that "Executive capacity of the highest degree should be demanded, and universities should vie with each other in turning out from their institutions' men adequately trained to serve their country as efficient police leaders" (Decker, 2018). At this moment in policing, one questions if the profession took Vollmer's assertions seriously. Notably, Vollmer attempted to assess and possibly forecast police leadership when he echoed Fosdick in American Police Systems by quoting him, "The irrational development of the American police organization is due to inadequate leadership" (Decker, 2018).

The focus on inadequate leadership then is directed at how we establish police leaders and through what means. Executive police hiring cannot be underestimated but must be emphasized. As leadership performance continues to mount, owning to concerns about police performance, police leadership has come under criticism in recent years, despite many attempts to improve the quality of executive leadership placement (Dobby, Anscombe \& Tufin, 2004). Within this current environment, we continually hear demands for police reform which, is critical and synonymous with effective police leadership. Dobby et al. (2004) emphatically suggests that police leadership needs to change to meet the calls and requirements of the police reform agendas. Essential in choosing proper leadership in the police reform effort is that leaders can influence followers to the extent to which they credibly take actions or make recommendations on behalf of the group. In this credibilitybuilding process, leader skills form an essential foundation to motivate followers to perceive leaders as credible role models (Zheng et al., 2019). A highly skilled expert placed in a leadership position can increase organizational effectiveness and police legitimacy in the eyes of the community, the key to police reform. Leadership is regarded as key to performance and improving police leadership is a central plank in the police reform agenda (Dobby et al., 2004). Finally, Michelson (2006) mentions that leadership in public safety agencies is at a critical crossroads and that in many communities, police leaders have left their departments. Many leaders have left their departments amid a crisis. Michelson (2006) also asserts that if the number of leaders vacating supervisory and management positions is as significant an issue as it appears, then it is necessary to consider just how to assess whether the next generation is ready to lead. The focus should be on developing critical skills, and less on one's perceived potential such as tenure which, allegedly coincides with knowledge and skill. In this article, we align necessary skills with conceptual and human skills in addition to the popular technical skills.

Leadership during Crisis. The protests related to the George Floyd murder in May of 2020 sparked off protests in America and around the world. The demonstrations and the Coronavirus have affected everyone 
and everything in our society. With policing being at the forefront, the policing profession was tested unlike never before since perhaps the '60s. These tumultuous times have swallowed up police leadership and regurgitated them back into other agencies, roles or, at times, spewed them out and into the realm of resignation or retirement. While it is true that; police leaders have a complex and challenging role whereas they find themselves balancing various demands related to organizational design and strategies and the needs of the community while simultaneously preparing the organization for the future (White \& Robinson, 2014). Police chiefs or police executives are tasked with managing those mentioned above and other challenging aspects that the department or organization may face.

Considering that police executives understand the degree of difficulty they face when accepting the position, it is noteworthy to discuss police executives' firings and resignations in cities across America during the summer protests of 2020. Dallas, Rochester, New York, Seattle, Nashville, Milwaukee, Fanwood, Las Cruces, Los Angeles, Tucson, Richmond, Atlanta, Portland, Louisville, and Prince Georges County all have lost their police executives during the summer of 2020 (Yancey-Bragg, 2020). Notably and most recently the U.S. Capitol police chief resigning in the first month of 2021 associated with a response which was seen by many as inadequate concerning the violent attack on the U.S. Capitol where at least five lives were lost. Admittingly, according to a U.S. Department of Justice report (2016), there are over a million police agencies (sworn and non-sworn) in the United States (Banks, Hendricks, Hickman \& Kyckelhahn, 2016). Still, one cannot ignore the police executives' departures of these major cities and the U.S. Capitol. It may be beneficial for current and future police leaders and concerned members of society to understand why we are experiencing an increased exodus of police executives during this complicated societal era. Like leadership in other organizations, police leadership continues to search for a successful formula for effectiveness within a society of changing demographics. When crime rates are low, and order is maintained, citizens feel safe and are satisfied with police service. As a quasi-military organization, police typically model their leadership or, at least, are significantly influenced by them (Brown, 2019). It is incredibly detrimental to the community and the specific agency members to finally ascertain that a police executive is not up to the task amid a crisis to the community's amazement. The question then is, when society is experiencing unrest or police are going through tumultuous times, how do we ensure that we have capable and effective police leadership already seated?

Considering that in the 21st century, police executives are more likely to face a crisis than not, hiring police leaders with the above in mind is critical. The purpose of this article is to suggest what is a viable approach to adopt what can be used as a malleable model when selecting police executives. In addressing how communities can ensure accomplished police leaders are hired, we must reflect on who and how they are selected. It is the goal to hire a capable albeit accomplished police executive. The latter accomplished, is defined as highly skilled expert (Kariger \& Fierro, 2021; Failex Inc., 2021). An important focal point is the distinction between accomplished and qualified. The definition of qualified is "having the qualifications for an office position or task (Failex Inc., 2021)" or "having complied with the specific requirements or precedent conditions" (Merriman-Webster, 2021). For the sake of this article, we submit that capable is noticeably closer to a highly skilled expert than qualified. A police chief's qualifications frequently used by hiring officials and Human Resource (HR) professionals in this present-day have been handed down decade after decade. They are heavy if not solely based on tenue and ascending through law enforcement agencies' ranks (qualifications), which given the subjective promoting of police throughout the country rarely correlates with being capable or a highly skilled expert. More on the subjectiveness of promotions later in the article. Concerning the selection of police executives, not much has changed over the years. The selection of law enforcement executives has seemed to have plagued policing for some time now, advocating more attention from researchers, practitioners, and society members. Over 20 years ago, Wood (1997) asserted that,

"It used to be that police chiefs came up through the ranks, chosen for their leadership ability and lawenforcement know-how. But these days, the person who sits in the corner office at police headquarters had also better be part publicist, customer-service rep, accountant, and politician - or risk losing the job"

By cause of a law enforcement executives meeting the archaic qualifications handed down decade after decade does not equate to capability in addressing the complexity of society's problems or, a highly skilled expert. The recent abrupt firings and resignations demonstrate police leaders' shortcomings to lead in the complexity of the 21st century. Police executives hiring left to the HR professionals using outdated qualifications as a measurement is insufficient in several aspects. Keep in mind that elements of leadership hiring are not exclusive to police chiefs' hiring. The distinction is that without a stable security sector, orderly society, and efficient and equitable policing, a weakened infrastructure is more probable. In contrast, other institutions, in 
addition to communities, are negatively affected. Although, unlike many other institutions, ineffective law enforcement agencies can result in bodily harm or even death.

Hiring Practices. Hiring practices, overall, have caught the attention of both practitioners and researchers over the last century with efforts for continuous improvements and research for best practices in selection processes being explored (Rozario, Venkatraman \& Abbas, 2019). Hiring officials must act and implement strategies to address the unsatisfactory hiring practices of police executives the profession has suffered from for some time. It is critical to address the gaps and subjectiveness in the hiring processes. Existing literature suggests that employers continue to trust their intuition and 'gut-feel', thereby unconsciously adopting a very subjective approach in executive leadership selection (Rozario et al., 2019). For these public servants, one crucial element that continues to be disregarded is community involvement, particularly in the hiring process of police executives. The community rarely has any input in a selection of a police chief. Admittingly, some jurisdictions have, in the past, provided the community access to the proposed police executives although, the practice is not consistent by any means.

In August of 2019, the City of West St. Paul, Minnesota, before selecting a new chief welcomed community involvement. The City of West St. Paul prepared a recruitment/selection process resulting in an appointment to the position. That process included an internal and external survey as well as a series of three Community/Candidate conversations. The above is an appreciable effort to include the community in the selection of the police chief. The internal survey process allowed for an additional assessment from the rank and file, albeit like a 360-degree feedback assessment. Conversely, the City of Baltimore attempting to include community involvement at and during the City appointment hearing. Members of the City Council Appointments Committee asked questions while the community observed never having a legitimate chance to question the proposed chief themselves. The result was a disgruntled community who refused to leave City Hall partly because of their not being afforded the ability and permission to participate in the hearing regarding legitimate social justice and over policing concerns. One of the protesters who left proclaimed, those remaining were "young people being young people and talking a lot about social justice." He continued to mention that the "level of commitment to social justice is empowering." Unfortunately, the well-intentioned but failed effort in Baltimore resulted in 16 arrests as the Committee approved the confirmation of the incoming chief. Perhaps, the overt message to the community is that their concerns do not matter, despite the comments from the incoming executive asserting otherwise. While there are many variables to be considered when engaging the community effectively, the above example by the City of West St. Paul is an impressive undertaking. All stakeholders, including Municipal, City, County, and State officials, must encourage and support overall community relationships with their police departments, including ensuring that the community has access to essential processes, including chief of police selection. Also, if police are engaging the community attempting to maintain a positive relationship, the profession cannot pick and choose which aspects of policing the community can access. A significant amount of police departments across the country, despite the size of the department, have and maintain written community policing plans as reported in 2020 (Table 1). It is time that those officials of their respective demographic areas also be held accountable and enhance community policing efforts by including the community in the chief and other command staff selection processes.

Table 1. Percent of local police departments that maintained a written community-policing plan, by size of population served, 2016

\begin{tabular}{|c|c|}
\hline Population served & Maintained a plan \\
\hline $1,000,000$ or more* & $80.0 \%$ \\
\hline $500,000-999,999$ & $72.4 \dagger$ \\
\hline $250,000-499,999$ & 78.0 \\
\hline $100,000-249,999$ & $61.7 \dagger$ \\
\hline $50,000-99,999$ & $62.3 \dagger$ \\
\hline $25,000-49,999$ & $56.6 \dagger$ \\
\hline $10,000-24,999$ & $51.1 \dagger$ \\
\hline $2,500-9,999$ & $37.9 \dagger$ \\
\hline 2,499 or less & $35.8 \dagger$ \\
\hline All departments & 42.1 \\
\hline All officers & 65.8 \\
\hline
\end{tabular}

Note: See appendix table 2 for standard errors.

* Comparison group.

+ Difference with comparison group is significant at the $95 \%$ confidence level.

$¥$ Difference with comparison group is significant at the $90 \%$ confidence level.

a Reflects the percentage of officers whose departments maintained a written community-policing plan. This is calculated by multiplying the result for each department by its size. The size of the department is the sum of the number of full-time sworn officers and part-time sworn officers (who are counted as the equivalent of 0.5 full-time sworn officers) employed by that department.

Source: Bureau of Justice Statistics, Law Enforcement Management and Administrative Statistics survey, 2016 
Always debatable are the challenges when selecting leaders, shall we consider that leaders are born as leaders, rely on trait leadership or, can leaders be made or developed i.e., process leadership. The trait leadership ideology based on intelligence, appearance, and the plethora of inherited traits often related to leadership is well known among leadership scholars. Process leadership conceptualizes leadership as contingent upon the quality of leader-follower relations and, most importantly, propounds leadership to its followers. The latter is more conducive to police leadership as the profession is a service-oriented one providing a service to the community's police serve. Additionally, seeking quality leader-follower relations is critical as leadership is mimicked and extends the concept of proper connections down to the rank and file advocating positive relations with the community. Not to omit the reasonability of having tenure or technical knowledge of the profession, which must not be the only qualification or focus of acquiring and developing a highly skilled professional.

How to Hire Executive Level Police Leaders. Katz wrote about a comprehensive approach to hiring, The Skills of an Effective Administrator published by Harvard Business Review where he outlined a broad hiring approach, the Three-Skill Approach. The Three-Skill Approach was later updated and expanded in Peter G. Northouse's Leadership: Theory and Practice Eighth Edition. Katz's initial research asserted that the approach rests on three necessary skills, Technical, Human, and Conceptual. Technical Skill is knowledge about proficiency gained in a specific field (tenure) or type of work or activity. Centered around knowledge and understanding and working with people are Human Skills. Conceptional Skill is the ability to work with ideas and concepts (Northouse, 2019). At the same time, there are many other leadership theories and approaches (Trait, Behavioral, Contingency, Situational, Style Approaches, and the age-old Great Man Theory) of calculating leadership styles, ideas, and traits albeit for this article, the example used will be the Three Skill Approach. The Skill Approach, rather than emphasizing what chief executives do, this approach frames leadership in the capabilities (skills) that make effective leadership possible (Northouse, 2019). Even today, this approach is a viable resource for hiring Administrators and Police Executives but only if used in its entirety. More often, we recognize that the selection of a police chief relies entirely on one aspect, technical skill certainly, before the interview process.

The unavoidable dilemma presents itself when HR professionals attempt to rely heavily or entirely on this single measure (technical) expecting to have a successful hiring practice acquiring a highly skilled expert. Insomuch, most of if not all the requirements when you dissect a police executives vacancy espouses primarily and only the technical skill portion of the Three Skill Approach. We tend to see two familiar desired qualifications. Simultaneously, these qualifications are not verbatim, but they are most apparent, easily recognized in the majority of police executive hiring announcements. The first, must have been in a Lieutenant position (or other specific ranks usually above Sergeant) or higher for 3-5 years, and second, completion of the FBI Academy is "highly desirable." The qualifications mentioned above are commendable measures, although, for the most part, these familiar and fundamental measures for the initial selection of an executive are void of human and conceptual skills, apart from the subjectiveness of the two examples provided.

A police executive selection cannot minimize or be lacking the two skills mentioned above, human and conceptual. Dobby et al. (2014) emphasize in their Police Leadership: Expectations and Impact comparison of police officers and police authority members' views on what makes a good police leader in respect to effectiveness. Table 2 from the study compares the evidence on what police leadership members look for from officers with the evidence on what police officers look for from their leadership (Dobby et al., 2014). The chart espouses a considerable number of human skills, i.e., 'displaying high personal and professional standards and challenging poor behavior,' 'treats people fairly and sensitively, and gains trust, respect, and community confidence,' among other aspects related to human skills in varying percentages.

Table 2. Comparison of the Views of Police Officers and Police Authority Members on What Makes Good Police Leader

\begin{tabular}{|c|c|}
\hline Police officers & Police authority (leadership) members \\
\hline $\begin{array}{c}44 \% \text { of the qualities thought by police officers to be related to } \\
\text { effective leadership were related to 'enabling, valuing and } \\
\text { developing staff' }\end{array}$ & $\begin{array}{c}47 \% \text { of police authority members felt 'gaining the trust, respect, and } \\
\text { confidence of staff, motivating, raising morale' was important for } \\
\text { Chief Officers. }\end{array}$ \\
\hline $\begin{array}{c}10 \% \text { of the qualities thought by police officers to be related to } \\
\text { effective leadership were related to 'being committed to } \\
\text { achieving a high-quality service' }\end{array}$ & $\begin{array}{c}26 \% \text { of police authority members mentioned 'Takes responsibility } \\
\text { for meeting needs, committed, sincere' and } 19 \% \text { mentioned } \\
\text { 'Committed, dedicated, determined, thorough, resilient, tenacious, } \\
\text { prepared to tackle crime' }\end{array}$ \\
\hline
\end{tabular}


Table 2 (cont). Comparison of the Views of Police Officers and Police Authority Members on What Makes Good Police Leader

\begin{tabular}{|c|c|}
\hline $\begin{array}{c}20 \% \text { of the qualities thought by police officers to be related to } \\
\text { effective leadership were related to 'displaying high personal } \\
\text { and professional standards and challenging poor behavior' }\end{array}$ & $\begin{array}{c}31 \% \text { of police authority members mentioned 'Treats people fairly, } \\
\text { sensitively', 24\% mentioned 'Has integrity, honesty', and } 26 \% \\
\text { mentioned 'Delegates, challenges, sets standards, monitors, } \\
\text { evaluates, drives continuous improvement' }\end{array}$ \\
\hline $\begin{array}{c}25 \% \text { of the qualities thought by police officers to be related to } \\
\text { effective leadership were related to 'having relevant knowledge } \\
\text { and skills' }\end{array}$ & $\begin{array}{c}35 \% \text { of police authority members mentioned 'Arrives at right } \\
\text { strategy to meet needs, skilled in planning', } 50 \% \text { mentioned 'Gains } \\
\text { trust, respect, confidence of community, markets force well, handles } \\
\text { media, good PR', and 25\% mentioned 'Manages resources } \\
\text { effectively and efficiently, good organization, effective use of } \\
\text { officers' }\end{array}$ \\
\hline
\end{tabular}

Source: Police Leadership: Expectations and Impact

Also, differing percentages are accounts related to conceptional skills such as 'delegates challenges, sets standards, monitors, evaluates, drives continuous improvement' and 'arrives at right strategy to meet needs, skilled in planning.' Not surprisingly, the qualitative data presented above can also advocate technical skill, indicating that effective leadership was related to 'having relevant knowledge and skills.' Notwithstanding, the quantitative data below (Table 3) regarding Leader Tenure (control) when associated with ethical leadership as a dependent variable reveals some interesting findings. Ethical leadership is a key component for police leadership and overall police reform. Ethical Leadership is leadership that is directed by the appreciation for moral beliefs and values, including the dignity and rights of others (Ethical Leadership, 2021).

Rai and Banerjee's (2019) study, The Role of Gender \& Leader Tenue in the Relationship between Spirituality \& Ethical Leadership conducts a regression analysis of Ethical Leadership and Leader Tenure amidst other controls. The analysis of Leader Tenure (dependent variable), and Fortitude, Introspective Reflection and Equanimity (independent variables) finds Leader Tenure negatively moderates several relationships. Particularly important for this study Rai and Banerjee's study finds; Leader Tenure negatively mediates the relationship between leader fortitude and subordinate's perception of ethnical leadership. It also concludes that Leader Tenure negatively mediates the relationship between leader equanimity and subordinate's perception of ethical leadership and finds Leader Tenure negatively mediates the relationship between leader spirituality and subordinate's perception of ethical leadership. Conspicuously the study finds no statistical significance for Leader Tenure negatively moderating the relationship between leader introspective reflection and subordinate's perception of ethical leadership. See table 3 below.

Table 3. Regression Analysis: Dependent Variable: Ethical Leadership

\begin{tabular}{|c|c|c|c|c|c|c|c|c|}
\hline \multirow[t]{2}{*}{ Independent Variable } & \multicolumn{2}{|c|}{ *Overall } & \multicolumn{2}{|c|}{ *Fortitude } & \multicolumn{2}{|c|}{$\begin{array}{c}* \text { Introspective } \\
\text { Reflection }\end{array}$} & \multicolumn{2}{|c|}{ *Equanimity } \\
\hline & Step 1 & Step 2 & Step 1 & Step 2 & Step 1 & Step 2 & Step 1 & Step 2 \\
\hline \multicolumn{9}{|l|}{ Control } \\
\hline Subordinate's tenure & .090 & .088 & .090 & .131 & .090 & .096 & .090 & -.006 \\
\hline $\begin{array}{l}\text { Subordinate's marital } \\
\text { status }\end{array}$ & -.104 & -.079 & -.104 & -.064 & -.104 & -.127 & -.104 & -.089 \\
\hline Subordinate's gender & -.234 & -.190 & -.234 & -.204 & -.234 & -.230 & -.234 & -.194 \\
\hline $\begin{array}{l}\text { Subordinate's } \\
\text { educational } \\
\text { qualification }\end{array}$ & -.006 & .013 & -.006 & .000 & -.006 & .026 & -.006 & -.018 \\
\hline Subordinate's age & -.060 & -.113 & -.060 & -.151 & -.060 & -.049 & -.060 & -.024 \\
\hline Leader's tenure & -.266 & -.161 & -.266 & -.259 & -.266 & -.200 & -.266 & -.121 \\
\hline Leader's Marital status & -.066 & .011 & -.066 & -.038 & -.066 & -.024 & -.066 & .003 \\
\hline Leader's gender & .078 & .117 & .078 & .103 & .078 & .050 & .078 & .162 \\
\hline Leader's Age & .141 & .166 & .141 & .170 & .141 & .138 & .141 & .148 \\
\hline $\begin{array}{l}\text { Leader's educational } \\
\text { qualification }\end{array}$ & -.133 & -.157 & -.133 & -.186 & -.133 & -.134 & -.133 & -.085 \\
\hline $\begin{array}{l}\text { Adjusted R-sq } \\
\text { (Control) }\end{array}$ & .040 & & & & & & & \\
\hline $\begin{array}{l}\text { Spirituality } \\
\text { Dimension* }\end{array}$ & & .403 & & .246 & & .282 & & .394 \\
\hline ÄR-Square & & 0.134 & & 0.052 & & 0.07 & & 0.119 \\
\hline
\end{tabular}

* denotes the regression coefficient of the Specified spirituality dimension.Figures in bold denote significant at the 0.05 level Source: The Indian Journal of Industrial Relations 
Ostensibly, tenure alone cannot only skew the hiring practice of potential leaders but as demonstrated, can negatively affect ethical leadership, its components, and relationships with subordinates. Recall, the article does not suggest that one should ignore tenure; it purports that tenure should not be the only skill measured. Admittingly, it indicates that if tenure exclusively is considered in leadership selection, not only will the probability of placing a highly skilled expert as an agency's leader be drastically diminished, tenure, if misused as a measure, is subjective.

\section{Subjective Measures}

The first example, an aspiring police executive must have acquired a Lieutenant position (or specific rank) or higher for several years, usually anywhere from 3 to 5 years in a medium to a large city. The announcements may or may not indicate the size of the town although to the credit of some HR professionals the size of the city is mentioned, usually medium or large sized city. This subjective measure or qualification is copious. This specific requirement suggests that all Lieutenants and police departments are somehow similar. Police departments vary in size and complexity of duties, let alone the supervisors' span of control. Brooks (2020) asserted that nearly half (48\%) of police departments in the U.S. employed fewer than ten officers and the average police department is 50 officers or less. By the U.S. census (2020), even the 200 largest cities have considerable disparities in police officers' numbers despite having comparable populations. San Bernardino, California (pop. 217,671) and Fayetteville, North Carolina (pop. 205,646) are both deemed to be large cities. The amount of sworn officers in San Bernardino is 255 and Fayetteville is approximately 430. The disparity in officers is momentous. Therefore, the span of control of all supervisors is much different, let alone the difference in communities that undoubtedly affect the contrast of police/community problems that police address.

Another complication with this measure is the disparity in obtaining the rank. Police may use promotional exams, sometimes coupled with other factors, to promote their respective officers. Many of these exams purport to measure "the knowledge, skills, and abilities" which can be practically and reliably measured, and which are required to perform the primary or dominant duties of the position, as required by civil service law (Brodin, 2018). It was determined that the Massachusetts Civil Service, Chicago, Houston, and Alexandria all used questions directly taken from their police manuals (Brodin, 2018). The proficiency of discerning a police manual has little to do with skills and ability, let alone any measure of leadership. Perhaps, more importantly, the disproportionate effect on persons of color and females as demonstrated by the many discriminatory suits filed based on unfair testing in cities such as Boston, Memphis, New Haven, Baltimore County, Bellville, Redding, Ann Arbor, among others. Brodin (2018) explains the inadequate testing measures and their disproportionate impact with the following statement.

"A public administration study confirms that written exams have historically been an obstacle for persons of color," perhaps "the biggest obstacle for police departments to achieve social diversity based on race and ethnicity. Yet there is little incentive to abandon them, given their low cost and ease of administration, as well as support from police unions."

These exams have little to do with predicting success as a Sergeant or other police supervisor. The second measure categorized within the technical skills set in many police chief hiring announcements is FBI Academy completion. While completing the FBI's valuable training is undoubtedly an asset for all police managers, including police chiefs, the problem with this measure is that it is subjective in how participants are chosen to participate in the training. The FBI website reads as follows.

"Leaders and managers of state, local, county, tribal, military, federal, and international law enforcement agencies attend the FBI National Academy. Participation is by invitation only, through a nomination process. Participants are drawn from every U.S. state and territory and from international partner nations".

The process leaves the nominations to the particular agency, an unregulated selection process of fairness, performance, or other qualifying measures. Again, the process, if any, is left up to the agency. The FBI National Academy offers a unique opportunity for training, although adding this measure to hire a police chief is subjective. One must have some vehicle, whereas they receive a nomination to attend the academy. Because of an agency's strong possibility of embodying an unwanted and unfair police culture (see reference to suits of unfair promotional exams above) enabling unfair practices within the agency and in that nomination process, the training must not be a necessary or even preferable measure. Accepting and applying the Three Skill Approach, the reliance on subjective measures and using only one skill, technical skills, without emphasizing human or conceptual skills results in a lack of understanding of the skills as mentioned acquired or present in 
the executive candidate. Furthermore, selecting a candidate without assessing the level of human or conceptional skills increases the probability of the selected candidate not having those skills yet seen as capable technically even though some of the technical measures are indeed subjective. The Skills Approach is not a trait model. Many criticize the use based on that premise even though if appropriately used, the Skills Approach can espouse various leadership traits within a police chief candidate.

\section{The Importance of a Proper Selection Process}

Regarding the departure of the chiefs who left office in 2020 and the onset of 2021, by whatever means does not suggest that they are entirely void of leadership qualities. There are many reasons why they may have left, and it is not sure exactly why they left, were relieved of duty, or resigned. But what we do know is that it leaves a void in leadership at the very time leadership is needed. Remember being qualified is different than being a highly skilled expert. Notwithstanding, one cannot help to consummate a perspective that the curtain has been pulled back comparable to the familiar scene in the Wizard of $O z$. Only this time, the curtain is a bulwark insulated by poor practices, systemic racism, unwanted culture [police], warrior mentality, and a refusal to be inclusive of the community they serve, all resulting in at the very least an inept leader. Sadly, this undeniable perspective is not limited to the policing profession. Policing does suffer from vast subjectiveness in police hiring practices in general, as outlined by the examples above. The result of the subjectiveness in police executive hiring affects the police agency in several ways. Most importantly, the result of not acquiring a highly skilled expert and the lack of opportunity to identify leadership capabilities is a significant shortcoming. As illustrated above, many agencies still espouse and operate within the discriminatory and disproportionate opportunities for Black and Brown men and females, chiefly if those mentioned above are not within the in-group or have not consented to the unwanted and harmful police culture.

Intentional or not, the exclusion of assessing human and conceptual skills creates a void or a gap in hiring police executives that the police agency and, more crucially, society cannot afford, lest we seat leadership who are incapable and ineffective. Highlighting the latter, effectiveness [police] can be elusive for the most capable leaders. It may be fool hearted to assume that leaders can build relationships and engage in stakeholder salience and social responsibility initiatives being void of these skills. Additionally, having personal mastery communicating to Government officials, Command Staff, rank and file, and community members that they must interact with regularly without assessing the essential human skill. Conceptualization or conceptual skill in the 21st must be assessed, let alone possessed, as a reliable skill. Conceptual skill can create and transcend a vision linking it to the proposed mission and espousing the values to attain that vision. Conceptual skill can assist in developing benchmarks, whereas the organization must move forward within a turbulent and everevolving society. It is the skill and ability to enable the community policing philosophy and apply policing strategies such as Intelligence Lead Policing, Problem-Oriented Policing, Directed Patrol, and other strategies or creating a comprehensive and effective strategy yet seen. All the above cannot be omitted or left to happenstance or luck.

There is no luck in human skill. It is something that highly skilled leaders spend a lifetime honing. The human skill involves being able to connect to people, most importantly, community. Bygone is the era of sitting in the pervertible Ivory Tower and passing orders down through the command staff onto the rank and file and public. Communities want to be involved, want to be addressed, and have questions about who is responsible for policing and how they are being policed. A critical part of the human skill involves being sensitive to the community, their needs, and empathetic to their challenges in an inequitable society. Human skill is not just how one interacts with superiors, politicians, and those with positional power. It is those who are powerless who need to be understood, who need to be engaged, who need to be assured that fairness is continually being pursued, their place in the community is significant, that they are a member of something, their community, and society. Police executives must have the human skill to ensure and assert that oppressed members of the community have a chance to achieve whatever they desire without participating in a crime, overall establishing we are the community, and we are best working together. It is that type of skill that is of the utmost importance; why would we not assess that within a police executive? 


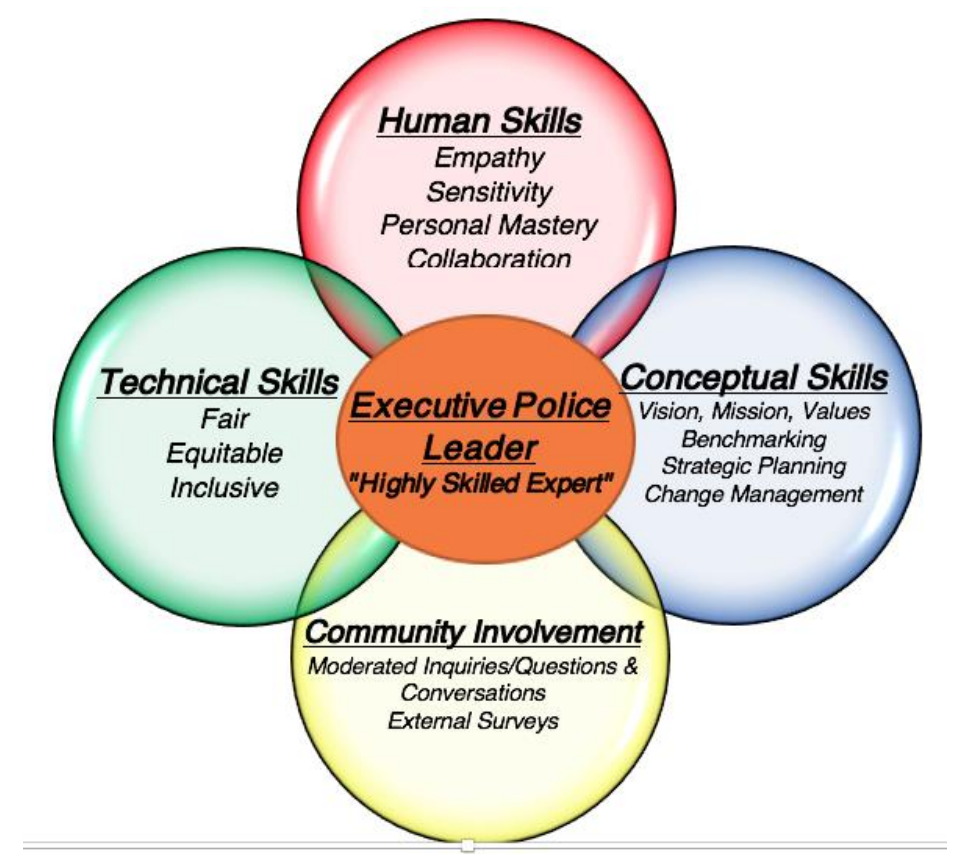

Figure 1. Components of a Highly Skilled Leader

Source: Compiled by the author

The author wants to reiterate that the Three Skill Approach is simply a resource used in this article to demonstrate how flawed the unilateral use of the widely relied upon technical skill measurement is. There are many available leadership assessment products which assess the various leadership skills, traits and competencies of a leadership candidate, some designed exclusively for police executives. The above discussion is essential for HR professionals and critical for the understanding of those members of the community who find themselves involved in assisting in the selection of an executive police chief.

Community Involvement is Mandatory. Being a part of the community means police executives must also be a part of the community for the collective good of that community. They begin to become one with the community in the early stages of assessing their Police executive ability. As with the example of West St. Paul, Minnesota, we (community) must encourage and insist on access to potential police executives' during the selection and appointment process. There are a multitude credible surveys already developed that community could engage in. Additionally, a series of community forums moderated by professionals and appropriately structured to interact with the proposed police executive is critical. At this early stage, police executives begin to establish a genuine partnership with the community, mainly if they are unknown to the community beforehand as many candidates are. Leadership is seen as a power relationship between followers [command staff and rank and file], but leaders must fairly and equitably share this power with the community. Police executives can no longer benefit from possessing all the power in a public service organization. The community deserves and must demand a power-sharing relationship with the top executive, and the rank and file. Communities must realize their voice defines what policing must be, equitable with resources available to and distributed to all community demographics. Policing is a function of public trust, although when the crucial decisions are absent of community input as to how policing occurs, we encounter problems like an aggressive and militarized response to peaceful protesters and inequitable and ineffective policing (Myers-Montgomery, 2016).

\section{Conclusion}

Selecting a police executive should be the community's responsibility, with government officials and HR professionals made available as a resource or tool for the community, not the other way around. Ensuring that the foundational template for evaluating a police executive candidate includes the three critical skills, human, conceptual and technical, and involving the community in the process while also assessing prior community collaboration must be considered a starting point and accepting anything less is inadequate. This article also touched upon the inequities of the police promotional process and how aspiring police leaders may be given preference in assignments but mainly training which, will later qualify them to be promoted even though this was not the main focus of the article. The latter must be addressed to level the playing field and ensure both men and women and those from various demographics are considered not just relatives, favorites, or those who consent to the unwanted culture that prohibits true police reform. Updating and addressing the selection process 
outlined in this article may be used as the template for promoting a highly skilled expert as the police executive. While the process may be lengthy and cost-intensive, it is more viable for seating an executive leader commensurate with leaders in other institutions and professions. A leader whose tenure after selection can endure more than one crisis, a leader who is a part of the community, and is a highly skilled expert. Equally important, a leader whose priority is the preservation of life in his or her community while being perceived and effective in the eyes of the community. When the Constitution, particularly the First and Fifth Amendment (right to freedom of speech, right to peacefully assembly and, the right to not deprive a person of life, liberty, and property without due process of the law) is trampled in favor of maintaining order and control, the citizens must take their communities and police leadership to task (Myers-Montgomery, 2016). Therefore, communities have the absolute right and must be seen as the intrinsic instrument in the police executive selection process.

Funding. There is no funding for this research.

\section{Reference}

1. Banks, D., Hendrix, J., Hickman, M., \& Kyckelhahn, T. (2016). National sources of law enforcement employment data. U.S. Department of Justice, Office of Justice Programs, Bureau of Justice Statistics. Report number: NCJ 249681. Available at: https://www.bjs.gov/content/pub/pdf/nsleed.pdf.

2. Brodin, M.S. (2018). Discriminatory job knowledge tests, police promotions, and what title VII can learn from tort law, 59 B.C.L. Rev. 2319. Available at: https://lawdigitalcommons.bc.edu/bclr/vol59/iss7/4.

3. Brooks, C. (2020). Local police departments, 2016: Personal policies and practices. Washington, D.C.: U.S. department of Justice. Available at: https://www.bjs.gov/index.cfm?ty=pbdetail\&iid=7006.

4. Brown, D. (2019). Perceived effective policing through leaderships' diversity training learning outcomes and cultural competence. Retrieved from ProQuest Dissertations Publishing (13810214). Available at: https://search.proquest.com/openview/6baac9559643d200d26a0844061ed04d/1?pqorigsite=gscholar\&cbl $=18750 \&$ diss $=\mathrm{y}$.

5. City of West St. Paul (2019). Police chief hiring input report, City of West St. Paul Minnesota. Available at: https://www.wspmn.gov/AgendaCenter/ViewFile/Item/8380?fileID=14776.

6. Decker, J. (2018). A study of transformational leadership practices to police officers' job satisfaction and organizational commitment. Seton Hall University Dissertations and Theses (ETDS). 2505. https://scholarship.shu.edu/dissertations/2505.

7. Dobby, J., Anscombe, J., \& Tuffin, R. (2004). Police leadership: Expectations and impact. Home Office Research, Development and Statistics. Available at: https://www.researchgate.netpublication/239574244_Police_Leadership_Expectations_and_Impact.

8. Ethical Leadership. (2021, April 1). In Wikipedia, the free encyclopedia. Available at: https://en.wikipedia.org/wiki/Ethical leadership.

9. Failex Inc. (2021). Qualified in Free dictionary.com. dictionary. Free Dictionary. Available at: https://www.thefreedictionary.com/qualified.

10.Fierro, D., \& Kariger, B. (2021). Accomplished in Dictionary.com dictionary. Dictionary. Available at: https://www.dictionary.com/browse/accomplished?s=ts.

11.Fierro, D., \& Kariger, B. (2021). Qualified in Dictionary.com dictionary. Dictionary. Available at: https://www.dictionary.com/browse/qualified?s=t.

12.Katz, R. (1974). Skills for an effective administrator: Leadership development, Harvard Business Review. Available at: https://hbr.org/1974/09/skills-of-an-effective-administrator.

13.Kim, J. (2018). The Effects of Relative Organizational Tenure on Job Behaviors in the Public Sector. Public Personnel Management, 47(3), 335-355. https://doi.org/10.1177/0091026017753646.

14.Michelson, R. (2006). Succession planning for police leadership. Police Chief magazine, June, 73(6), 16-22. Available at: https://www.policechiefmagazine.org/succession-planning-and-intentional-leadership/.

15.Merriman-Webster (2021). Qualified in Merriman-webster.com. dictionary. Merriman-Webster Dictionary. Available at: https://www.merriam-webster.com/dictionary/qualified.

16.Myers-Montgomery, J. (2016). Militarized police and unpermitted protest: implementing policy that civilizes the police. Cultural Studies Critical Methodologies, 16(3), 278-286. https://doi.org/10.1177/1532708616634774.

17.Northouse, P.G. (2019). Leadership: Theory and practices. Eighth edition. Los Angeles: SAGE Publications, Inc. Available at: https://scholarworks.wmich.edu/books/739/.

18.Haake, U., Rantatalo, O., \& Lindberg, O. (2015). Police leaders make poor change agents: leadership practice in the face of a major organizational reform, Policing and Society. https://doi.org/10.1080/10439463.2015.1099653. 
19.Rai, H., \& Banerjee, B. (2019). The role of gender \& leader tenure in the relationship between spirituality and ethical leadership. Indian Journal of Industrial Relations, 54(3), 497-515. Available at: http://www.publishingindia.com/ijir/22/the-role-of-gender-and-leader-tenure-in-the-relationship-betweenspirituality-and-ethical-leadership/775/5383/.

20.Rozario S.D., Venkatraman S., \& Abbas, A. (2019). Challenges in recruitment and selection process: An empirical study. Challenges 10(2), 35. https://doi.org/10.3390/challe10020035.

21.Schofield, D. L. (1993). Hiring standards. FBI Law Enforcement Bulletin, 62(11), 27-32. Available at: https://www.ojp.gov/ncjrs/virtual-library/abstracts/hiring-standards-ensuring-fitness-duty.

22.Wheatley, M.J. (1999). Leadership and the new science: Discovering order in a chaotic world. San Francisco: Berrett-Koehler Publishers. Available at: https://margaretwheatley.com/booksproducts/books/leadership-new-science/.

23.White, V., \& Robinson S. (2014). Leading change in policing: Police culture and the psychological contract. The Police Journal, 87(4), 258-269. https://doi.org/10.1350/pojo.2014.87.4.675.

24.Wood, D.B. (1997). Many hats of modern police chief. Christian, Science Monitor, 89(71), 1. Available at: https://www.csmonitor.com/1997/0310/031097.us.us.2.html.

25. Yancey-Bragg, N. (2020). More than a dozen police chiefs faced backlash-and left-after George Floyd's death. Here's a list. USA Today. Available at: https://www.usatoday.com/story/news/nation/2020/09/09/george-floyd-death-police-chiefs-fired-resignabruptly-retire-list/5755934002/.

26.Zheng, Y., Graham, L., \& Epitropakil, O. (2019). Service leadership, work engagement and service performance: The moderating role of leader skills. Sage Publications, 45(1), 1-32. https://doi.org/10.1177/1059601119851978. 